\title{
Wolbachia is present in Apis mellifera capensis, A. m. scutellata, and their hybrid in Southern Africa
}

\author{
Marjorie A. HoY ${ }^{\mathrm{a} *}$, Ayyamperumal JeYAPRAKASH ${ }^{\mathrm{a}}$, Juan M. AlvAREZ ${ }^{\mathrm{a}, \mathrm{b}}$, \\ Michael H. ALLSOPP
}

\begin{abstract}
a Department of Entomology and Nematology, University of Florida, Gainesville, Florida, USA 32611
b Now at the Aberdeen Research and Education Center, University of Idaho, Aberdeen, Idaho, USA 83210

c Honeybee Research Section, Plant Protection Research Institute, Agricultural Research Council, Private Bag 5017, Stellenbosch 7599, South Africa
\end{abstract}

(Received 2 January 2002; revised 21 June 2002 ; accepted 2 July 2002)

\begin{abstract}
Apis mellifera capensis, A. m. scutellata and their hybrids were screened by a sensitive Long PCR protocol for Wolbachia because this endosymbiont has been implicated in causing thelytoky in other Hymenoptera. Wolbachia was found in all workers of A. m. capensis examined, and in workers and drones of A. m. scutellata and in hybrid workers of these two subspecies. Cloning and sequencing indicated that all contained the same unique Wolbachia strain, named $w$ Cap-B1, which belongs to the Con Group because it displayed less than $2.5 \%$ sequence divergence from the reference strain from Tribolium confusum. $w$ CapB1 is closely related to Wolbachia from Diaphorina citri, Solenopsis invicta, Coleomegilla maculata lengi, Plutella xylostella, and Bemisia tabaci. Because no sequence differences were found among these bee populations, infection with this Wolbachia strain is unlikely to be associated with thelytoky in $A . m$. capensis.
\end{abstract}

Apis mellifera capensis / Apis mellifera scutellata / Wolbachia / Long PCR / thelytoky

\section{INTRODUCTION}

In most populations of Apis mellifera L., females are produced from fertilized queenlaid eggs while males are haploid and are produced from unfertilized queen-laid eggs. Unfertilized eggs also can be produced by worker honeybees under queenless conditions. In all races of Apis mellifera except the Cape honeybee, A. m. capensis Escholtz, these unfertilized eggs are produced by arrhenotokous parthenogenesis and give rise to haploid males (Ruttner, 1988). In the case of workers of the Cape honeybee, however, unfertilized eggs are produced by thelytokous parthenogenesis and give rise to diploid females (Onions, 1912;
Ruttner, 1988). Some colonies of A. m. capensis and hybrids of A. m. capensis and A. m. scutellata Lepeletier exhibit both arrhenotokous and thelytokous worker reproduction (Hepburn and Crewe, 1991).

The ability of Cape honeybee workers to produce female progeny is central to the 'Cape Honeybee Problem' in South Africa where, since 1990, A. m. capensis workers have invaded A. m. scutellata colonies, causing the loss of many tens of thousands of colonies (Allsopp, 1992; Oldroyd, 2002). Research into the unique features of Cape honeybees has included investigating the genetic basis of thelytoky in A. m. capensis (Crewe and Allsopp, 1994). The basis of the capensis phenotype

\footnotetext{
* Correspondence and reprints

E-mail: mahoy@mail.ifas.ufl.edu
} 
has been studied by many (Oldroyd, 2002). The genetics basis of the thelytoky could be due to either nuclear or cytoplasmic genetic factors, or interactions between them. One possibility is that the thelytoky is caused by Wolbachia in A. m. capensis.

Wolbachia is one of the most common cytoplasmically inherited microorganisms in arthropods and its effects on their hosts include altering sex ratio or inducing thelytoky (Rigaud and Rousset, 1996; O'Neill et al., 1997; Werren, 1997; Cook and Butcher, 1999). Wolbachia are gram-negative bacteria and are widespread, with 17 to $76 \%$ of all arthropod species infected with one or more strains (Werren et al., 1995; Werren, 1997; Jeyaprakash and Hoy, 2000). Wolbachia have been found in numerous species of Hymenoptera, including parasitoids and ants (Stouthamer, 1997; Cook and Butcher, 1999; Shoemaker et al., 2000; Wenseleers et al., 1998; Jeyaprakash and Hoy, 2000). Wolbachia induces thelytoky in at least 40 species of Hymenoptera (Cook and Butcher, 1999); in a number of cases, the thelytokous insects have been 'cured' of Wolbachia after treatment with antibiotics or heat shock and arrhenotokous reproduction has been restored (Zchori-Fein et al., 1992; Cook and Butcher, 1999; Stouthamer, 1997). However, the presence of Wolbachia in hymenopteran species does not always induce thelytoky and a full understanding of the evolution and physiological and phenotypic effects of Wolbachia on their arthropod hosts is lacking (Rigaud, 1999; Weeks et al., 2002). Recently, for example, Dedeine et al. (2001) found that Wolbachia were necessary for oogenesis in the parasitoid Asobara tabida and its removal led to sterility, suggesting that the presence of Wolbachia in this species is obligatory.

The presence of Wolbachia in social Hymenoptera, including the Cape bee, was investigated by Wenseleers and Billen (2000) using a Standard PCR protocol to amplify $16 \mathrm{~S}$ rDNA sequences from A. m. capensis and several species of ants, but they were unable to find Wolbachia in A. m. capensis. Because we had discovered that a Standard PCR protocol was six to eight orders of magnitude less sensitive than a Long PCR protocol in amplifying Wolbachia sequences from a diverse array of arthropod species (Jeyaprakash and Hoy, 2000), we decided to reinvestigate the status of Wolbachia in A. m. capensis. If A. m. capensis contained Wolbachia, but A. m. scutellata did not, further research into the possible role of Wolbachia as the causal agent of the thelytoky seen in A. m. capensis would be warranted.

This paper compares the sensitivity of the Long and Standard PCR protocols in amplifying a portion of a Wolbachia surface coat protein gene ( $w s p$ ) from southern African populations of $A$. m. capensis, A. m. scutellata, and hybrids between them. The Wolbachia $w s p$ sequences obtained were cloned and sequenced. The role of Wolbachia in inducing thelytoky in A. m. capensis is discussed.

\section{MATERIALS AND METHODS}

\subsection{Colony sources}

Bees were collected into 95\% EtOH by M. Allsopp from colonies of A. m. scutellata, A. m. capensis and hybrids of these two subspecies in southern Africa (South Africa and Zimbabwe) and shipped to the University of Florida for analysis (Tab. I). A. $m$. capensis samples were collected from Robben Island and Stellenbosch in the Western Cape of South Africa. Because the 'Capensis Problem' has resulted in $A$. m. capensis being present through much of South Africa that was inhabited formerly only by A. $m$. scutellata, the A. $m$. scutellata sample was collected from northern Zimbabwe to ensure its purity. A sample of hybrids of the two races was collected from Grahamstown in the Eastern Cape of South Africa (Hepburn and Crewe, 1991).

\subsection{DNA extraction and PCR protocols}

Single bees were used to extract DNA using Puregene reagents (Gentra Systems, Minneapolis, $\mathrm{MN}$ ) and the genomic DNA was resuspended in $50 \mu \mathrm{L}$ of sterile water. $1 \mu \mathrm{L}$ genomic DNA preparation was used for PCR amplification.

Primers (30-mers, Wsp-F, 5'-TGGTCCAA TAAGTGATGAAGAAACTAGCTA-3' and Wsp-R, 5'-AAAAATTAAACGCTACTCCAGCTTCTGC AC-3') were designed from the Wolbachia wsp gene sequence of Drosophila simulans (GenBank [http:// www.ncbi.nlm.nih.gov] Accession AF020070) to amplify a variable region of about $0.6 \mathrm{~kb}$ (Braig et al., 1998).

Standard PCR was performed by the hot start method in a $25 \mu \mathrm{l}$ volume containing $10 \mathrm{mM}$ Tris 
Table I. Colony source and type of A. mellifera subspecies from southern Africa tested for the presence of Wolbachia by the Long PCR protocol using wsp primers.

\begin{tabular}{ll}
\hline Site number & Source (type) \\
\hline 1 & Robben Island drones (capensis or hybrids)* \\
2 & Robben Island workers (capensis or hybrids)* \\
3 & Stellenbosch1 drones (pure capensis) \\
4 & Stellenbosch1 workers (pure capensis) \\
5 & Zimbabwe160 workers (pure scutellata)** \\
9 & Stellenbosch2 workers (pure capensis) \\
17 & Grahamstown1 workers (hybrids) \\
\hline
\end{tabular}

* Robben Island bees tested should be pure capensis. Although A. m. scutellata were kept there 25 years ago, and there are minute traces of $A$. m. scutellata on the island, the bees are "basically 100\% pure capensis" (M. Alsopp).

** All other bees were collected in South Africa.

(pH 8.3), $1.5 \mathrm{mM} \mathrm{MgCl2,} 50 \mathrm{mM} \mathrm{KCl,} 200 \mu \mathrm{M}$ dATP, dGTP, dCTP, dTTP, 400 picomoles of primers and 0.8 unit Taq DNA polymerase (Roche Molecular Biochemicals, Indianapolis, IN) (Saiki, 1989). The PCR was performed using 35 cycles, each consisting of denaturation at $94{ }^{\circ} \mathrm{C}$ for $30 \mathrm{~s}$ and annealing and extension at $72^{\circ} \mathrm{C}$ for $1 \mathrm{~min}$.

Long PCR was performed in a $50 \mu \mathrm{L}$ volume containing $50 \mathrm{mM}$ Tris $(\mathrm{pH} 9.2), 16 \mathrm{mM}$ ammonium sulfate, $1.75 \mathrm{mM} \mathrm{MgCl} 2,350 \mu \mathrm{M}$ dATP, dGTP, dCTP, dTTP, 800 picomoles of primers (Wsp-F and Wsp-R), 1 unit of $P$ wo and 5 units of Taq DNA polymerases (Barnes, 1994). The DNA template, buffer and enzymes were mixed in $25 \mu \mathrm{L}$ volume and combined with a $25 \mu \mathrm{L}$ volume containing the primers and dNTPs; both mixes were kept on ice prior to starting the amplification. The Long PCR was carried out using three linked profiles over 36 cycles; (i) 1 cycle of denaturation at $94{ }^{\circ} \mathrm{C}$ for $2 \mathrm{~min}$, (ii) 10 cycles each consisting of denaturation at $94^{\circ} \mathrm{C}$ for $10 \mathrm{~s}$, annealing at $65^{\circ} \mathrm{C}$ for $30 \mathrm{~s}$ and extension at $68^{\circ} \mathrm{C}$ for $1 \mathrm{~min}$, and (iii) 25 cycles each consisting of denaturation at $94{ }^{\circ} \mathrm{C}$ for $10 \mathrm{~s}$, annealing at $65^{\circ} \mathrm{C}$ for $30 \mathrm{~s}$ and extension at $68{ }^{\circ} \mathrm{C}$ for $1 \mathrm{~min}$, plus an additional $20 \mathrm{~s}$ added for every consecutive cycle between 11 and 36 .

The PCR products were electrophoresed on $2 \%$ agarose gels with TBE buffer with a Roche DNA size marker VI producing bands ranging from 2176 to $154 \mathrm{bp}$ in lane I.

Table I lists the site numbers and bees evaluated. DNA isolated from five bees each from sites $1,2,3$, and 4 were amplified by both Long and Standard PCR protocols on February 3, 2000 by A. Jeyaprakash, using the same DNA to compare the relative efficiency of the protocols. On September 6, 2000, J.M. Alvarez isolated DNA from two bees each from sites 5, 9 and 17 and amplified the DNA by the Long PCR protocol. On August 3, 2001
DNA from two additional bees each from sites 5, 9, and 17 were tested by the Long PCR protocol by A. Jeyaprakash. On October 12, 2001, DNA from five bees from site 5 was amplified by both the Standard and Long PCR by A. Jeyaprakash.

Long PCR products were purified using QIAquick PCR purification column (QIAGEN Inc., Valencia, CA) and cloned into the plasmid pCR2.1TOPO using the procedure suggested by the manufacturer (Invitrogen Corporation, Carlsbad, CA). DNA sequencing was performed at the University of Florida ICBR Core Facility using a PERKINELMER Applied Biosystems ABI PRISM Automated DNA Sequencer. Clean laboratory practices, sealed pipette tips, and fresh reagents were used to avoid contamination. Negative controls (consisting of all components except the DNA template) were conducted on each date to detect potential contamination, but positive controls were not carried out to reduce the likelihood of contamination.

The wsp sequences obtained were compared with wsp sequences found by a BLAST search of GenBank.

\section{RESULTS AND DISCUSSION}

\subsection{Wolbachia DNA amplification by Standard and Long PCR protocols}

Amplification of $w s p$ sequences from $A$. $m$. capensis, A. $m$. scutellata and a hybrid between them by the Standard PCR protocol with the wsp primers never produced a product (partial data shown in Fig. 1). Comparisons were made using the same DNA as a template for both the Standard and Long PCR protocols 


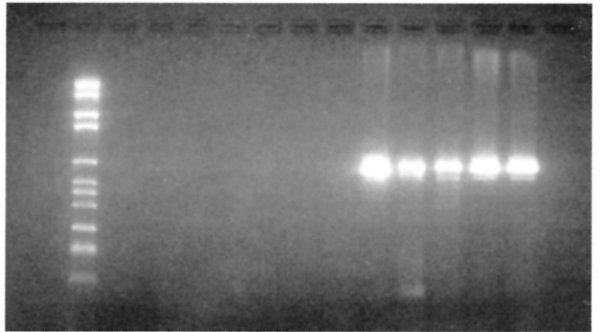

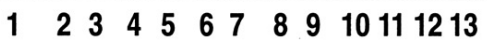

Figure 1. Long PCR was successful in amplifying the $0.6 \mathrm{~kb}$ wsp sequence of Wolbachia from five individuals of A. m. scutellata (lanes 9-13) from southern Africa, although the same DNA template when used in a Standard PCR protocol failed to yield a product (lanes 3-7). Lane 1 is DNA Marker VI and shows bands; lanes 2 and 8 are 'no template DNA' controls.

on February 3, 2000 and again on October 12, 2001 . None of the 26 bees analyzed by Standard PCR yielded a product. By contrast, DNA from 36 of 37 bees examined by the Long PCR provided a PCR product of the expected length. The failure to obtain a PCR product by Standard PCR and wsp primers confirms the negative results obtained by Wenseleers and Billen (2000) with 16S rDNA primers for a population of A. m. capensis. By contrast, the Long PCR protocol gave positive results, consistently producing a band approximately $0.6 \mathrm{~kb}$ in size, as expected.

Long PCR products were obtained from populations of $A$. m. capensis, A. $m$. scutellata and the hybrid of these two races on each of the three dates the bees were tested and by two different people. PCR products were never obtained in the no-DNA controls, indicating that contamination was not responsible for these positive results (partial data shown in Fig. 1).

A sensitivity analysis conducted previously by Jeyaprakash and Hoy (2000), using cloned wsp sequences, indicated that Long PCR is approximately six to eight times more sensitive than Standard PCR in amplifying Wolbachia wsp and 16S rDNA sequences from diverse arthropod species. Although Standard PCR protocols have been used widely to amplify Wolbachia sequences, little information is available on the frequency of false negatives. Long PCR amplifies cloned Wolbachia wsp sequences consistently when mixed with insect DNA, even when there are as few as 100 copies of the plasmid present (Jeyaprakash and Hoy, 2000). Likewise, the Long PCR protocol was more sensitive than the Standard PCR when the nusG-rplK segment of a plantpathogenic bacterium (Liberobacter) was amplified from insects and citrus foliage (Hoy et al., 2001). The level of sensitivity obtained in these two prior experiments, along with the results of this survey of southern African bees, suggests that Long PCR is substantially more effective in amplifying microbial DNA when mixed with insect genomic DNA. Long PCR is effective in increasing sensitivity and fidelity (Barnes, 1994); whether the failure to detect Wolbachia in these bees by Standard PCR is due to inhibition of the reaction or to a low titer of Wolbachia is unknown.

\subsection{Wolbachia sequence analysis}

A Long PCR product from a site-1 bee (Robben Island drone, capensis) was cloned by A. Jeyaprakash and three clones were sequenced in February 2000. All three sequences were identical, indicating that there was only one type of Wolbachia present in this individual (Tab. II). Long PCR products from a bee from site-5 (Zimbabwe160 worker, pure scutellata) were cloned by J.M. Alvarez in September 2000 and two clones had identical sequences (Tab. II). The wsp sequences obtained on October 12, 2001 by A. Jeyaprakash were cloned and six independent transformants from each population (site-5, Zimbabwe 160 worker, pure scutellata; site-9, Stellen-bosch2 worker, pure capensis; and site-17, Grahamstown1 worker hybrids) were sequenced; all sequences were identical (Tab. II). Only one $w s p$ sequence was obtained from the Long PCR products cloned from $A$. m. scutellata, A. m. capensis, and hybrids between them (sites 1, 5, 5, 9, 17) on three different dates by two different people. This consistency indicates that all populations and individuals tested had a single Wolbachia infection.

The Wolbachia wsp sequence is unique and was named $w$ Cap-B1 following the guidelines used by Zhou et al. (1998). The sequence was submitted to Genbank under accession number AF510085. The $w$ Cap-B1 $w s p$ sequence belongs 
Table II. All Wolbachia wsp sequences obtained from A. m. capensis, A. m. scutellata and a hybrid between them from Zimbabwe and South Africa were unique, but identical to each other.

CTACGTTCGTTTACAATACAACGGTGAAATTTTACCTTTTTATACAAAAGTTGATGG
TATTACAAATGCAACAGGTAAAGAAAAGGGTAGTCCCTTAACAAGATCTTTTATAG
CTGGTGGTGGTGCATTTGGTTATAAAATGGATGACATTAGAGTTGATGTTGAAGGG
CTTTACTCAAAATTGGCTAAAGATACAGATGTAGTAAATACTTCTGAAACAAATGT
TGCAGACAGTTTAACAGCATTTTCAGGATTGGTTAACGTTTATTACGATATAGCGAT
TGAAGATATGCCTATCACTCCATACGTTGGTGTTGGTATTGGTGCAGCATATATCAGC
AATCCTTCAAAAGCTGATGTAGTTAAAGATCAAAAAGGATTTGGTTTTGCTTATCA
AGCAAAAGCTGGTGTTAGCTATGATGTAACTCCAGAAATCAAACTCTTTGCTGGA
GCTCGTTACTTCGGTTCTTATGGTGCTAGTTTTGATAAGGCAGCTAAGGATGATACT
GGTATCAAAAATGTTGTTTACAGCACTGTTG

to the Con Group because it displayed less than $2.5 \%$ sequence divergence from the BWolbachia reference strain from Tribolium confusum (Coleoptera). The BLAST search indicated the $w$ Cap-B1 wsp sequence is closely related to wsp sequences from Diaphorina citri, Homoptera; Solenopsis invicta, Hymenoptera; Coleomegilla maculata lengi, Coleoptera; Plutella xylostella, Lepidoptera; and Bemisia tabaci, Homoptera (Zhou et al., 1998; Jeyaprakash and Hoy, 2000; Nirgianaki et al., unpublished).

The fact that the $w s p$ sequences are identical could be due to relatively recent horizontal transfer between $A$. m. scutellata and $A$. $m$. capensis or to vertical transfer to these subspecies from a common ancestor. Because $A$. $m$. scutellata and A. m. capensis can interbreed (and their hybrid had an identical sequence) the evidence for horizontal transfer appears stronger than the evidence for vertical transfer from a common ancestor because we would expect some sequence variation, especially in the third codon through genetic drift, if the Wolbachia were present in the common ancestor. Additional species of Apis and subspecies of A. mellifera from different geographic regions will have to be examined to resolve this issue. Natural horizontal transfer of Wolbachia appears to be common, but little is known about the mechanism(s) (Cook and Butcher, 1999).

\subsection{The Wolbachia phenotype}

Because individuals of $A$. $m$. scutellata, A. $m$. capensis, and their hybrid all tested positive for a single strain of Wolbachia, this strain of Wolbachia is unlikely to be the causal agent of thelytoky in $A$. m. capensis. Although we found no evidence that these bees contained more than one strain of Wolbachia, multiple infections are relatively common in arthropods (Jeyaprakash and Hoy, 2000) and thus additional strains of Wolbachia might be detected in future analyses of $A$. m. capensis. If $A$. m. capensis is found to contain a second strain of Wolbachia, it is possible that thelytoky could be due to it. However, parthenogenesis-inducing Wolbachia in parasitoids cause a failure in segregation during anaphase I, which restores diploidy with complete homozygosity (Stouthamer, 1997) and this is a different cytological mechanism than that reported for $A$. $m$. capensis (Verma and Ruttner, 1983). Because Wolbachia is reported to cause other cytological distortions, including the terminal fusion of the pronucleus and polar body in the parasitoid Aphytis mytilaspidis (Rossler and DeBach, 1973; Stouthamer, 1997), Wolbachia could be potentially involved in thelytoky in A. m. capensis.

Although some strains of Wolbachia are associated with cytoplasmic incompatibility, thelytoky, male killing and feminization, many arthropods infected with Wolbachia have no obvious phenotype associated with its presence (Jeyaprakash and Hoy, 2000; Weeks et al., 2002). Unfortunately, investigations of the role this Wolbachia strain plays in the biology of its hosts will have to be deferred until it can be eliminated from the bees. Preliminary efforts (M. Allsopp, unpublished) to cure $A$. $m$. capensis colonies by feeding queens with $20 \mathrm{mg} / \mathrm{mL}$ of rifampicin or $20 \mathrm{mg} / \mathrm{ml}$ tetracycline failed due to the complete mortality of the treated individuals. 
Thelytoky in A. $m$. capensis could be induced by microorganisms other than Wolbachia. Recent investigations by Zchori-Fein et al. (2001) indicate that bacteria other than Wolbachia can be associated with parthenogenesis in the hymenopteran parasitoids Encarsia pergandiella and E. hispida. The ability to induce thelytokous parthenogenesis thus is not unique to Wolbachia or even to the Proteobacteria to which Wolbachia belong because the bacteria causing thelytoky in Encarsia were affiliated with the CytophagaFlexibacter-Bacteroid (CFB) group (ZchoriFein et al., 2001). Additional analyses of microbial symbionts of $A$. m. capensis could reveal similar surprises.

\section{ACKNOWLEDGEMENTS}

We thank M.T. Sanford for discussions. Partial funding was provided through the Davies, Fischer and Eckes Endowment for Biological Control at the University of Florida. This is Florida Agricultural Experiment Station journal publication R-08537.

Résumé - Wolbachia est présent chez Apis mellifera capensis, $A$. $m$. scutellata et chez leurs hybrides. Des populations d'Apis mellifera capensis, d'A. m. scutellata et de leurs hybrides sont présentes en Afrique du Sud. Bien qu'une étude précédente ait échoué à détecter la présence de Wolbachia par un protocole standard de l'amplification en chaîne par polymérase (PCR) et par des amorces $16 \mathrm{~S}$, un protocole plus sensible de PCR long, utilisant des amorces pour la séquence $w s p$, a été utilisé pour déterminer si Wolbachia pouvait être présent (Tab. I). A. m. capensis a cette caractéristique inhabituelle qu'elle se reproduit par thélytokie, ce qui est parfois induit chez les Arthropodes par Wolbachia. Wolbachia a été mis en évidence par le protocole de PCR long chez toutes les ouvrières d' A. $m$. capensis examinées, chez les ouvrières et les mâles d'A. $m$. scutellata et chez les hybrides des deux races. Comme l'on s'y attendait, le protocole standard moins sensible de PCR n'a pu fournir de produits wsp détectables (Fig. 1). Le clonage et le séquençage des produits de PCR ont indiqué que tous les individus et les populations d'Afrique du sud testés renfermaient la même souche de Wolbachia (Tab. II). La séquence wsp était inédite et a été nommée $w$ Cap-B1. Elle appartient au groupe Con de Wolbachia parce qu'elle présente moins de $2,5 \%$ de divergence avec la souche de référence Wolbachia-B provenant de Tribolium confusum
(Coleoptera). La séquence $w$ Cap-B1 est étroitement apparentée à Wolbachia de Diaphorina citri (Homoptera), de Solenopsis invicta (Hymenoptera), de Coleomegilla maculata lengi (Coleoptera), de Plutella xylostella (Lepidoptera) et de Bemisia tabaci (Homoptera).

Puisqu'on n'a pas trouvé de différences de séquence chez la souche de Wolbachia de ces populations d'abeilles, il est peu vraisemblable que ce Wolbachia soit associé à la thélytokie chez $A$. $m$. capensis. Les spéculations concernant le rôle que cette souche de Wolbachia joue dans la biologie de son hôte devront être repoussées jusqu'à ce qu'il puisse être éliminé des abeilles. Des efforts préliminaires (M. Allsopp, non publié) pour soigner les colonies d'A. $m$. capensis en nourrissant les reines avec $20 \mathrm{mg} / \mathrm{mL}$ de rifampicine ou $20 \mathrm{mg} / \mathrm{mL}$ de tétracycline ont échoué en raison de la mortalité de tous les individus traités.

Les infections multiples par Wolbachia sont relativement communes chez les Arthropodes (Jeyaprakash et Hoy, 2000) et d'autres souches de Wolbachia pourraient donc être détectées lors de futures analyses d'A. m. capensis. Si une seconde souche de Wolbachia est trouvée chez A. m. capensis, il se peut que la thélytokie lui soit due. A l'inverse, la thélytokie chez A. m. capensis pourrait être causée par la présence d'autres micro-organismes. Les recherches récentes sur les guêpes parasitoïdes par Zchori-Fein et al. (2001) indiquent que d'autres bactéries sont susceptibles de provoquer la thélytokie et l'on a montré que de nombreux microorganismes agissaient sur la production de mâles chez les insectes (Weeks et al., 2002).

La capacité à induire la thélytokie n'est pas restreinte à Wolbachia, ni même aux Proteobacteria, auxquelles Wolbachia appartient ; une bactérie nouvellement découverte est affiliée au groupe Cytophaga-Flexibacter-Bacteroid (CFB) (ZchoriFein et al., 2001). D'autres analyses de symbiotes microbiens d'A. $m$. capensis pourraient révéler des surprises semblables.

Apis mellifera capensis / Apis mellifera scutellata / Wolbachia / PCR long / thélytokie

Zusammenfassung - Nachweis von Wolbachia in Apis mellifera capensis, A. m. scutellata und ihren Hybriden in Süd Afrika. In Südafrika gibt es Populationen von Apis mellifera capensis, A. m. scutellata und deren Hybriden. In einer früheren Untersuchung bei $A$. m. capensis gelang es nicht, Wolbachia mit einem Standard PCR Protokoll und 16S Primern nachzuweisen. Jetzt wurde die empfindlichere Methode des Long PCR Protokolls mit Primern für die $w s p$ Sequenz zur Überprüfung des Vorkommens von Wolbachia benutzt (Tab. I). 
Die Vermehrung der A. $m$. capensis ist ein Sonderfall, da sie auch durch Thelytokie erfolgen kann. Thelytokie wird manchmal bei Arthropoden durch Wolbachia ausgelöst. Wolbachia wurde mit dem Long PCR Protokoll in allen untersuchten Arbeiterinnen von A. m. capensis nachgewiesen, allerdings auch in Arbeiterinnen und Drohnen von A. m. scutellata sowie bei den Hybriden der beiden Rassen. Wie erwartet erhielten wir mit der Standard PCR Methode keine erkennbaren wsp Produkte (Abb. 1). Clonierung und Sequenzierung der PCR Produkte wies darauf hin, dass bei allen überprüften südafrikanischen Einzeltieren und Populationen dieselben Linien von Wolbachia vorkamen (Tab. II). Die wsp Sequenz war neuartig und wurde $w$ Cap-B1 genannt. Sie gehört zu der Con Gruppe von Wolbachia und weist weniger als 2,5\% Abweichung von der B-Wolbachia Referenzlinie von Tribolium confusum (Coleoptera) auf. Die $w$ Cap-B1 Sequenz ist nah verwandt mit Wolbachia von Diaphorina citri, Homoptera; Solenopsis invicta, Hymenoptera; Coleomegilla maculata lengi, Coleoptera; Plutella xylostella, Lepidoptera; und Bemisia tabaci, Homoptera.

Da keine Sequenzunterschiede in der Wolbachia Linie in diesen Bienenpopulationen gefunden wurde, ist es unwahrscheinlich, dass Wolbachia mit der Thelytokie bei A. m. capensis in Zusammenhang steht. Spekulationen über die Bedeutung dieser Wolbachia Linien in Bezug auf die Biologie ihres Wirtes müssen zurück gestellt werden, bis es gelingt die Bienen befallsfrei zu machen. Vorläufige Bemühungen (M. Allsopp, nicht publiziert) A. m. capensis Völker durch Fütterung der Königinnen mit $20 \mathrm{mg} / \mathrm{ml}$ Rifampicin oder $20 \mathrm{mg} / \mathrm{ml}$ Tetracyclin zu heilen, blieben durch das Absterben aller behandelten Tiere ohne Erfolg. Mehrfache Infektionen mit Wolbachia sind relativ häufig in Arthropoden (Jeyaprakash and Hoy, 2000) und so könnten noch zusätzliche Linien von Wolbachia in zukünftigen Analysen von A. m. capensis entdeckt werden. Wenn der Nachweis einer zweiten Linie Wolbachia in A. m. capensis gelingen sollte, wäre es möglich, dass Thelytokie auf einer solchen Linie beruht. Alternativ könnte die Thelytokie in $A . m$. capensis auch von der Anwesenheit anderer Mikroben abhängig sein. Neuere Untersuchungen von parasitären Wespen durch Zchori-Fein et al. (2001) weisen darauf hin, dass andere Bakterien Thelytokie auslösen können und bei einer Vielzahl von Mikroorganismen konnte ein Einfluss auf die Produktion von Männchen bei Insekten gezeigt werden (Weeks et al., 2002). Die Fähigkeit zur Induktion von Thelytokie ist demnach nicht auf Wolbachia beschränkt, noch nicht einmal auf Proteobakterien zu denen Wolbachia zählt. Ein neu entdecktes Bakterium wird der Gruppe der CytophagaFlexibacter-Bakteroiden (CFB) zugeordnet (ZchoriFein et al., 2001). Zusätzliche Analysen von mikrobiellen Symbionten bei A. m. capensis könnte $\mathrm{zu}$ ähnlichen Überraschungen führen.

\section{Apis mellifera capensis / Apis mellifera scutellata / Wolbachia / Long PCR / Thelytokie}

\section{REFERENCES}

Allsopp M.H. (1992) The capensis calamity, South Afr. Bee J. 64, 52-55.

Barnes W. (1994) PCR amplification of up to $35-\mathrm{kb}$ DNA with high fidelity and high yield from $\lambda$ bacteriophage templates, Proc. Natl. Acad. Sci. USA 91, 2216-2220.

Braig H.R., Zhou W., Dobson S.L., O'Neill S.L. (1998) Cloning and characterization of a gene encoding the major surface protein of the bacterial endosymbiont Wolbachia pipientis, J. Bacteriol. 180, 2373-2378.

Cook J.M., Butcher R.J.D. (1999) The transmission and effects of Wolbachia bacteria in parasitoids, Res. Popul. Ecol. 41, 15-28.

Crewe R.M., Allsopp M.H. (1994) Sex and the single queen: recent experiments with capensis and scutellata queens, South Afr. Bee J. 66, 58-62.

Dedeine F., Vavre F., Fleury F., Loppin B., Hochberg M.E., Bouletreau M. (2001) Removing symbiotic Wolbachia bacteria specifically inhibits oogenesis in a parasitic wasp, Proc. Natl. Acad. Sci. USA 98, 6247-6252.

Hepburn H.R., Crewe R.M. (1991) Portrait of the Cape honeybee, Apis mellifera capensis, Apidologie 22, 567-580.

Hoy M.A., Jeyaprakash A., Nguyen R. (2001) Long PCR is a sensitive method for detecting Liberobacter asiaticum in parasitoids undergoing risk assessment in quarantine, Biol. Control 22, 278-287.

Jeyaprakash A., Hoy M.A. (2000) Long PCR improves Wolbachia DNA amplification: wsp sequences found in $76 \%$ of 63 arthropod species, Insect Mol. Biol. 9, 393-405.

O'Neill S.L., Hoffmann A.A., Werren J.H. (Eds.) (1997) Influential passengers, Oxford Univ. Press, Oxford.

Oldroyd B.B. (2002) The Cape honeybee: an example of a social cancer, Trends Ecol. Evol. 17, 249 251.

Onions G.W. (1912) South African "fertile-worker bees", South Afr. Agric. J. 1, 720-728.

Rigaud T. (1999) Further Wolbachia endosymbiont diversity: a tree hiding in the forest? Trends Ecol. Evol. 14, 212-213.

Rigaud T., Rousett F. (1996) What generates the diversity of Wolbachia-arthropod interactions, Biodiv. and Conserv. 5, 999-1013. 
Rossler Y., DeBach P. (1973) The biosystematic relations between a thelytokous and arrhenotokous form of Aphytis mytilaspidis. I. The reproductive relations, Entomophaga 17, 391-423.

Ruttner F. (1988) Biogeography and taxonomy of honeybees, Springer-Verlag, Berlin.

Saiki R.K. (1989) The design and optimization of the PCR, in: Erlich H.A. (Ed.), PCR technology, Stockton Press, New York, pp. 7-16.

Shoemaker D.D., Ross K.G., Keller L., Vargo E.L., Werren J.H. (2000) Wolbachia infections in native and introduced populations of fire ants (Solenopsis spp.), Insect Mol. Biol. 9, 661-673.

Stouthamer R. (1997) Wolbachia-induced parthenogenesis, in: O'Neill S.L., Hoffmann A.A., Werren J.H. (Eds.), Influential passengers, Oxford Univ. Press, pp. 102-124.

Verma S., Ruttner F. (1983) Cytological analysis of the thelytokous parthenogenesis in the Cape honeybee (Apis mellifera capensis Escholtz), Apidologie 14, 41-57.

Weeks A.R., Reynolds K.T., Hoffmann A.A. (2002) Wolbachia dynamics and host effects: what has (and has not) been demonstrated? Trends Ecol. Evol. 17, 257-262.
Wenseleers T., Billen J. (2000) No evidence for Wolbachia-induced parthenogenesis in the social Hymenoptera, J. Evol. Biol. 13, 277-280.

Wenseleers T., Ito F., van Borm S., Huybrechts R., Volckaert F., Billen J. (1998) Widespread occurrence of the micro-organism Wolbachia in ants, Proc. R. Soc. London B 265, 1447-1452.

Werren J.H. (1997) Biology of Wolbachia, Annu. Rev. Entomol. 42, 587-609.

Werren J.H., Windsor D., Guo L. (1995) Distribution of Wolbachia among neotropical arthropods, Proc. R. Soc. London B 262, 197-204.

Zchori-Fein E., Roush R.T., Hunter M.S. (1992) Male production influenced by antibiotic treatment in Encarsia formosa, an asexual species, Experientia 48, 102-105.

Zchori-Fein E., Gottlieb Y., Kelly S.E., Brown J.K., Wilson J.M., Karr T.L., Hunter M.S. (2001) A newly discovered bacterium associated with parthenogenesis and a change in host selection behavior in parasitoid wasps, Proc. Natl. Acad. Sci. USA 98, 12555-12560.

Zhou W., Rousset F., O'Neill S.L. (1998) Phylogeny and PCR-based classification of Wolbachia strains using wsp gene sequences, Proc. R. Soc. London B 265, 509-515. 